\title{
Effect of extremely low-concentration gaseous chlorine dioxide against surface Escherichia coli, Pseudomonas aeruginosa and Acinetobacter baumannii in wet conditions on glass dishes
}

\author{
Hirofumi Morino ${ }^{1,2^{*}}$ (D) Masafumi Futatsukame ${ }^{1,2}$, Takanori Miura ${ }^{1,2}$ and Takashi Shibata ${ }^{1,2}$
}

\begin{abstract}
Objective: Healthcare-associated infections due to Gram-negative bacteria (GNB) are a major cause of mortality and morbidity throughout the world. The purpose of the research described here was to evaluate the possibility of using an extremely low-concentration gaseous chlorine dioxide $\left(\mathrm{ClO}_{2}, 0.01 \mathrm{ppmv}, 0.028 \mathrm{mg} / \mathrm{m}^{3}\right)$ as a technique to reduce the risk of environmental infection by GNB. In this study we set up an exposure chamber $\left(1 \mathrm{~m}^{3}\right)$ and used three types of GNB, namely Escherichia coli, Pseudomonas aeruginosa and Acinetobacter baumannii.

Results: The extremely low-concentration gaseous $\mathrm{ClO}_{2}$ inactivated $E$. coli ( $>2 \log _{10}$ reductions, within $2 \mathrm{~h}$ ), P. aeruginosa (> $4 \log _{10}$ reductions, within $2 \mathrm{~h}$ ) and A. baumannii ( $>2 \log _{10}$ reductions, within $3 \mathrm{~h}$ ) in wet conditions on glass dishes. Treatment of moist environments with extremely low-concentration gaseous $\mathrm{ClO}_{2}$ may help to reduce the risk of environmental infection by GNB without harmful effects.
\end{abstract}

Keywords: Chlorine dioxide, Gas, Bacteria, Escherichia coli, Pseudomonas aeruginosa, Acinetobacter baumannii

\section{Introduction}

Healthcare-associated infections (HAIs) due to Gramnegative bacteria (GNB) are a major cause of mortality and morbidity throughout the world [1]. Many GNB cause respiratory tract infections; these include Pseudomonas aeruginosa, Escherichia coli, Acinetobacter baumannii and Klebsiella pneumonia [2]. In a previous study, we showed that gaseous chlorine dioxide $\left(\mathrm{ClO}_{2}\right.$, CAS No. 10049-04-4) in a low concentration (mean 0.05 ppmv, $0.14 \mathrm{mg} / \mathrm{m}^{3}$ ) inactivates $E$. coli in wet conditions on a glass surface [3]. Recently, Ogata et al. reported that

\footnotetext{
*Correspondence: morino@seirogan.co.jp

${ }^{1}$ Taiko Pharmaceutical Co., Ltd., Uchihonmachi 3-34-14, Suita, Osaka

564-0032, Japan

Full list of author information is available at the end of the article
}

extremely low-concentration gaseous $\mathrm{ClO}_{2}(0.01 \mathrm{ppmv}$, $0.028 \mathrm{mg} / \mathrm{m}^{3}$ ) inactivated airborne bacteria and viruses [4]. This concentration is only $1 / 10$ of the threshold limit value $\left(0.1 \mathrm{ppmv}, 0.28 \mathrm{mg} / \mathrm{m}^{3}\right)$ for gaseous $\mathrm{ClO}_{2}$ defined by the American Occupational Safety and Health Administration (OSHA) as an $8 \mathrm{~h}$ time-weighted average [5]. Based on that report, we speculated that extremely lowconcentration gaseous $\mathrm{ClO}_{2}$ can also inactivate bacteria on surfaces. To investigate the efficacy of extremely lowconcentration gaseous $\mathrm{ClO}_{2}$ against surface bacteria, we set up an exposure chamber $\left(1 \mathrm{~m}^{3}\right)$, which can maintain a constant, extremely low- concentration of the gas. In this study, we used three types of bacterium, namely $E$. coli, $P$. aeruginosa and $A$. baumannii. The purpose of this study is to evaluate the usefulness of this treatment with extremely low-concentration gaseous $\mathrm{ClO}_{2}$ as a 
technique to reduce the risk of infection by environmental GNB without harmful effects.

\section{Main text}

\section{Materials and methods}

\section{Test bacteria and preparation}

Preparation of the test bacteria followed our previous report with some modifications [3]. E. coli NBRC 3972, $P$. aeruginosa NBRC 13275 and A. baumannii NBRC 110494 were obtained from the Biological Resource Center (NITE, Japan). Each bead from the stock vials (PL.170/M, Microbank ${ }^{\mathrm{TM}}$, Pro-Lab Diagnostics Inc., U.S.A.) of E. coli and P. aeruginosa stored at $-80{ }^{\circ} \mathrm{C}$ was transferred into $5 \mathrm{ml}$ of Soybean Casein Digest (SCD) broth (393-00185, Nihon Seiyaku, Japan). Incubation was carried out in a shaking incubator at $200 \mathrm{rpm}$ for $18 \mathrm{~h}$ at $37{ }^{\circ} \mathrm{C}$. One bead from a stock vial of $A$. baumannii was transferred onto a SCD agar plate (51048, Nissui Pharmaceutical Co., LTD., Japan) and incubated at $37{ }^{\circ} \mathrm{C}$ for $18 \mathrm{~h}$. Cells of $E$. coli and P. aeruginosa were collected by centrifugation at $1400 \times g$ for $15 \mathrm{~min}$ at room temperature. Cells of $A$. baumannii on the agar plate were collected with an inoculating loop. These bacteria were washed three times with Dulbecco's phosphate buffer saline (D-PBS). The bacteria were resuspended in D-PBS and adjusted to an $\mathrm{OD}_{660}$ of $0.1\left(1 \times 10^{8}\right.$ cells $\left./ \mathrm{ml}\right)$. These bacteria were used for inoculation.

A $100 \mu \mathrm{l}$ aliquot of the bacterial suspension $\left(1 \times 10^{8}\right.$ cells $/ \mathrm{ml}$ in D-PBS) was placed on $5 \mathrm{~cm}$ diameter glass dishes. In this study, bacteria on the glass dishes did not undergo a drying process. The dishes were placed in the $1 \mathrm{~m}^{3}$ exposure chamber described below. The preparations were exposed to $0.01,0.03 \mathrm{ppmv} \mathrm{ClO}_{2}$ gas or air (control) for 0, 1, 2 and $3 \mathrm{~h}$. Subsequently, $120 \mu \mathrm{l}$ of SCD medium with $1 \mathrm{mM} \mathrm{Na}_{2} \mathrm{~S}_{2} \mathrm{O}_{3}$ as neutralizer was added to the glass dishes after the exposure to air or $\mathrm{ClO}_{2}$ gas. The bacteria on the glass dishes were collected using a cell scraper (179693, Thermo Fisher Scientific, U.S.A.).

\section{Determination of viable counts}

The bacteria samples were serially diluted tenfold and $100 \mu \mathrm{l}$ of diluted bacteria was inoculated on SCD agar. The bacteria were cultured at $35^{\circ} \mathrm{C}$ for 24 to $48 \mathrm{~h}$ and the number of colonies on SCD agar was counted. The viable cell counts were determined as colony forming units $(\mathrm{CFU}) /$ dish.

\section{Exposure chamber}

We prepared a cubic exposure chamber $\left(1 \mathrm{~m}^{3}\right)$ to evaluate the bactericidal effect of the extremely low concentration gaseous $\mathrm{ClO}_{2}$ (Fig. 1a). The $\mathrm{ClO}_{2}$ gas was introduced into the exposure chamber by a $\mathrm{ClO}_{2}$ gas generator which was made in our laboratory. The humidity in the

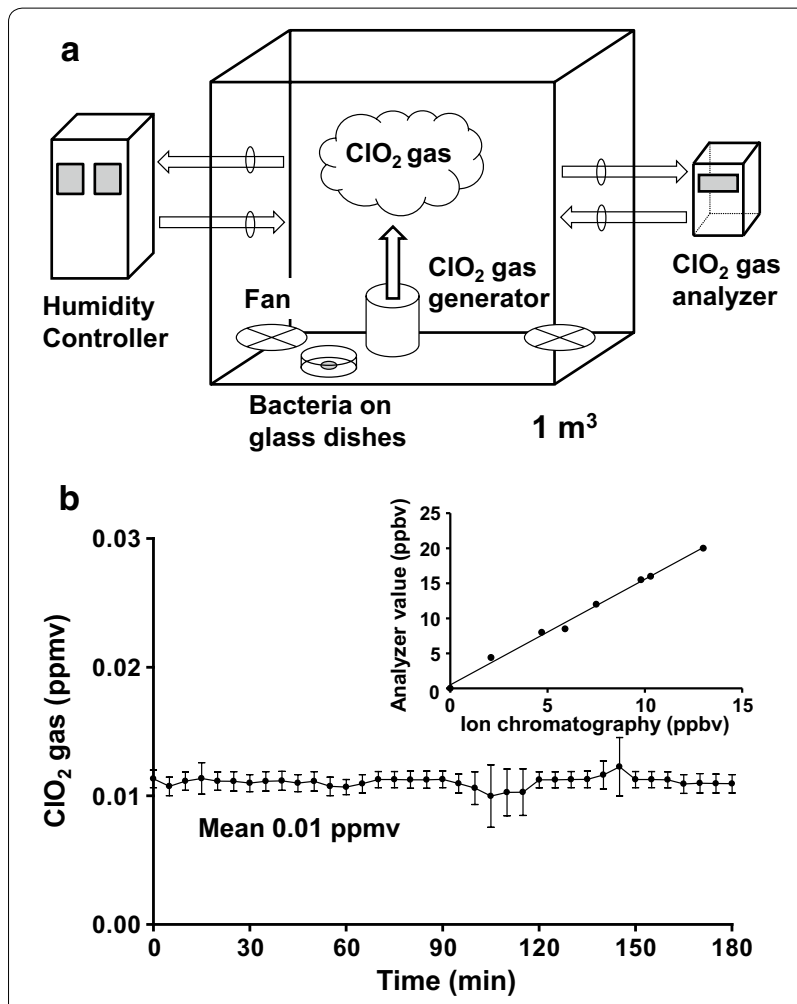

Fig. 1 Illustration of the exposure chamber setup and changes in the concentration of gaseous $\mathrm{ClO}_{2}$ in the exposure chamber. a Schematic diagram of bacteria on glass dishes in an exposure chamber. The bacteria were placed in $1 \mathrm{~m}^{3}$ exposure chamber in wet conditions on glass dishes. $\mathbf{b}$ Changes in the concentration of gaseous $\mathrm{ClO}_{2}$ in the exposure chamber. The error bar in the graph indicates S.D. $(n=4)$. The inset shows correlation between gaseous $\mathrm{ClO}_{2}$ concentrations (ppbv) by ion chromatography versus measurements using $\mathrm{ClO}_{2}$ gas analyzer

exposure chamber was constantly controlled by a humidity controller (ADPAC-N1000-AH, ADTEC Corporation, Japan). To maintain a homogeneous concentration of $\mathrm{ClO}_{2}$ gas in the exposure chamber, the contained air was constantly circulated using two fans (MU1225S-11, ORIX, Japan). The glass dishes inoculated with bacteria were placed in the exposure chamber. The concentration of gaseous $\mathrm{ClO}_{2}$ in the exposure chamber was measured by a $\mathrm{ClO}_{2}$ gas analyzer (Midas Gas Detector, MIDAS-E-BR2, Honeywell Analytics, IL, U.S.A.). Furthermore, the determination of concentration of $\mathrm{ClO}_{2}$ gas was performed using an established protocol (OSHA Method ID-202) with some modifications. Briefly, the $\mathrm{ClO}_{2}$ gas was collected in a midget impinger (1448-02, SOGORIKAGAKU GLASS WORKS, Japan) containing $20 \mathrm{ml}$ of $1.2 \mathrm{mM}$ potassium iodide $(\mathrm{KI})$ in a $1.5 \mathrm{mM}$ $\mathrm{Na}_{2} \mathrm{CO}_{3} / 1.5 \mathrm{mM} \mathrm{NaHCO}$ buffer solution at $0.5 \mathrm{~L} / \mathrm{min}$ for $20 \mathrm{~min}$. The collected $\mathrm{ClO}_{2}\left(\right.$ as $\left.\mathrm{ClO}_{2}{ }^{-}\right)$was analyzed by an ion chromatograph (ICS-3000, Thermo Fisher 
Scientific (DIONEX), U.S.A.). The temperature and relative humidity in the exposure chamber were measured by a thermo-hygrometer (TR-72 wf, T\&D, Japan; accuracy of $\pm 0.3^{\circ} \mathrm{C}$ and $\left.\pm 2.5 \% \mathrm{RH}\right)$.

\section{Statistical analysis}

The presence of any significant difference was determined by Student's $t$ test (two-tailed).

\section{Results}

Determination of gaseous $\mathrm{ClO}_{2}$ concentration in the exposure chamber

The concentration of gaseous $\mathrm{ClO}_{2}$ measured by the gas analyzer in the exposure chamber is shown in Fig. 1b. As shown in Fig. 1b (inset), there was a linear correlation between gaseous $\mathrm{ClO}_{2}$ concentrations determined by ion chromatography and measurements by the $\mathrm{ClO}_{2}$ gas analyzer; the line was then fitted to a linear function by regression analysis. The values obtained by the $\mathrm{ClO}_{2}$ gas analyzer were corrected using the regression equation. The coefficient of determination $R^{2}$ of this fitting was 0.994 . The average value of concentration of gaseous $\mathrm{ClO}_{2}$ was $0.01 \pm 0.001 \mathrm{ppmv}$. The temperature and relative humidity in the exposure chamber were $24.4 \pm 0.2^{\circ} \mathrm{C}$ and $56.6 \pm 1 \%$, respectively.

\section{Bactericidal activity of gaseous $\mathrm{ClO}_{2}$ at extremely low concentrations}

We evaluated the bactericidal activity of gaseous $\mathrm{ClO}_{2}$ at extremely low-concentrations against E. coli, P. aeruginosa and $A$. baumannii in wet conditions on glass dishes. The bactericidal activity of gaseous $\mathrm{ClO}_{2}$ against E. coli exhibited reductions of $>2 \log _{10}$ (mean $0.01 \mathrm{ppmv}$, $p<0.05$ ) and $>4 \log _{10}$ (mean 0.03 ppmv, $p<0.05$ ) after $2 \mathrm{~h}$ as compared to the control values (Fig. 2a). The bactericidal activity of gaseous $\mathrm{ClO}_{2}$ against $P$. aeruginosa exhibited reductions of $>4 \log _{10}$ (mean 0.01 ppmv, $p<0.01$ ) after $2 \mathrm{~h}$ as compared to the control values and achieved undetectable levels $(<1 \mathrm{CFU} /$ dish) after $3 \mathrm{~h}$ (mean 0.03 ppmv, $p<0.05$ ) (Fig. 2b). The bactericidal activity of gaseous $\mathrm{ClO}_{2}$ against $A$. baumannii showed reductions of $>2$ $\log _{10}$ (mean 0.01 ppmv, $p<0.01$ ) and $>4 \log _{10}$ (mean 0.03 ppmv, $p<0.01)$ after $3 \mathrm{~h}$ as compared to the control values (Fig. 2c).

\section{Bactericidal activity of gaseous $\mathrm{ClO}_{2}$ under dirty conditions}

Efficacy of gaseous $\mathrm{ClO}_{2}$ against microbes in wet conditions was decreased in the presence of fetal bovine serum (FBS) as an organic substance [3]. Hence, we examined the effect of an FBS load (0, 3, 5 and 10\%) on the inactivation of $P$. aeruginosa, which had the highest sensitivity to gaseous $\mathrm{ClO}_{2}$ of the three evaluated bacteria, with a $\mathrm{ClO}_{2}$ gas of concentration of 0.01 ppmv. The extremely

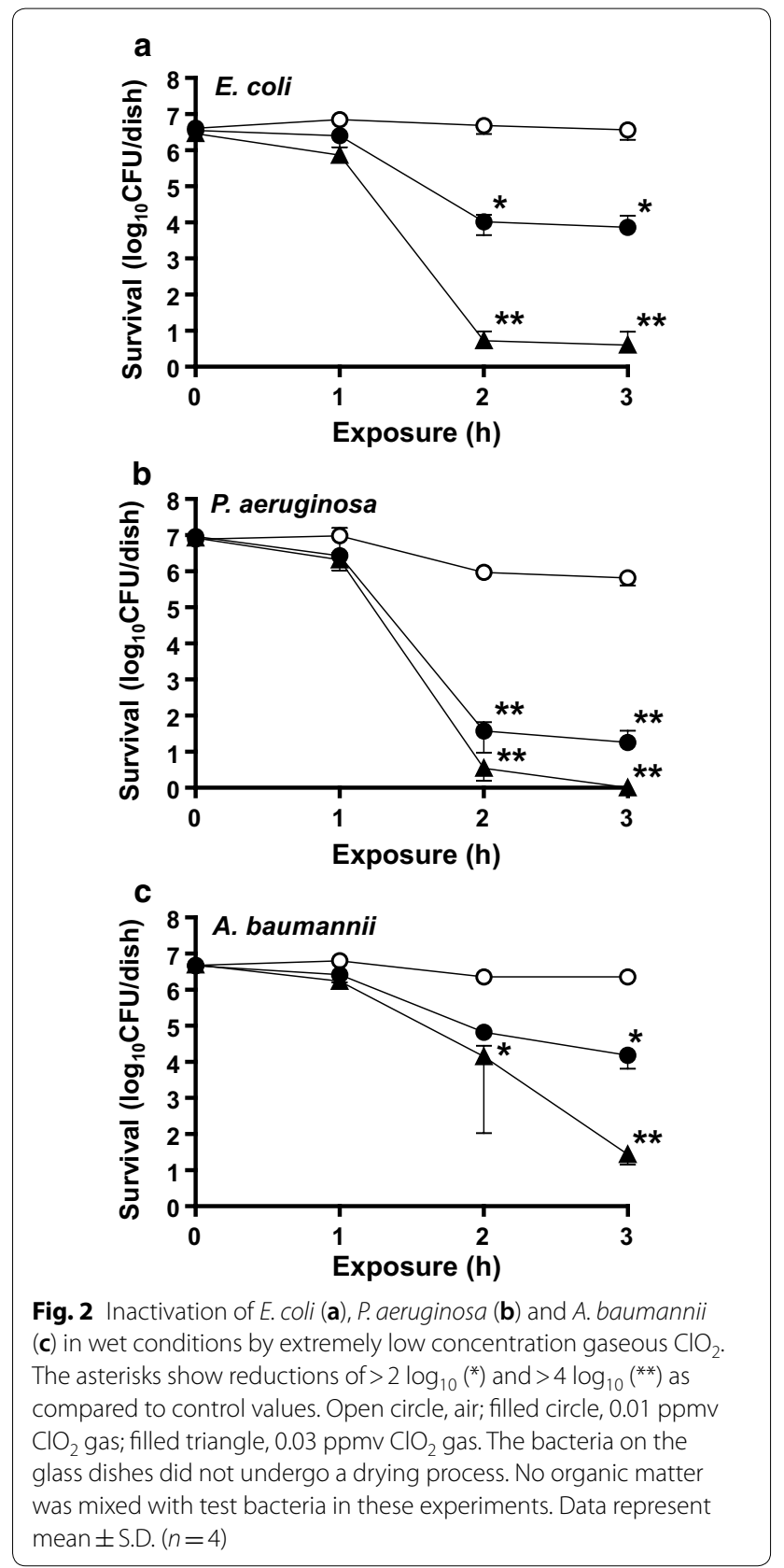

low- concentration gaseous $\mathrm{ClO}_{2}(0.01 \mathrm{ppmv})$ inactivated P. aeruginosa with 5\% FBS (2.9 $\log _{10}$ reductions) within $3 \mathrm{~h}$ (Table 1).

\section{Discussion}

Gaseous agents and disinfectant vapors have excellent diffusive characteristics. Such agents can disinfect areas where liquid agents are difficult to use. However, many procedures using formaldehyde, peracetic acid, etc. have disadvantages, for example, skin inflammation 
Table 1 Effect of organic substance load on bactericidal activity against $P$. aeruginosa of extremely low concentration gaseous $\mathrm{ClO}_{2}$ in wet conditions

\begin{tabular}{llll}
\hline $\begin{array}{l}\text { Exposure time } \\
\text { (h) }\end{array}$ & $\begin{array}{l}\text { FBS concentration } \\
\text { in bacterial suspension (\%) }\end{array}$ & $\begin{array}{l}\text { P. aeruginosa } \\
\text { survival (log } \\
\text { CFU/dish) }\end{array}$ \\
\cline { 3 - 4 } & & Air & $\mathrm{ClO}_{\mathbf{2}}$ \\
\hline 3 & 0 & 6.2 & $0.1\left(6.1^{\mathrm{b}}\right)$ \\
& 3 & 7.0 & $3.3\left(3.7^{\mathrm{a}}\right)$ \\
& 5 & 6.9 & $4.0\left(2.9^{\mathrm{a}}\right)$ \\
& 10 & 6.7 & $5.2(1.5)$
\end{tabular}

Values in parentheses in the table indicate $\log _{10}$ reduction. Survival values of $P$. aeruginosa indicate reductions of ${ }^{\mathrm{a}}>2 \log _{10}$ and ${ }^{\mathrm{b}}>4 \log _{10}$ as compared to control values (Air). Data represent mean value $(n=4)$

and acute toxicity for the respiratory system. According to the OSHA, the threshold limit value for gaseous $\mathrm{ClO}_{2}$ is $0.1 \mathrm{ppmv}$ as an $8 \mathrm{~h}$ time-weighted average. The extremely low-concentration gaseous $\mathrm{ClO}_{2}(0.01 \mathrm{ppmv})$ used to inactivate GNB in this research was only $1 / 10$ of that concentration. In a previous study, we demonstrated that gaseous $\mathrm{ClO}_{2}$ at $0.1 \mathrm{ppmv}$ was not toxic when whole bodies of rats were exposed to the gas for 6 months [6]. Furthermore, Ogata et al. reported that the no observed adverse effect level (NOAEL) of gaseous $\mathrm{ClO}_{2}$ was 1 ppmv [7]. From these results, we think that use of extremely low- concentration gaseous $\mathrm{ClO}_{2}(0.01 \mathrm{ppmv})$ is a feasible method for inactivating GNB in the presence of humans, without adverse effects.

In this study, the bactericidal activity against multidrug-resistant (MDR)-GNB of gaseous $\mathrm{ClO}_{2}$ of extremely low-concentration was not determined. However, a $\mathrm{ClO}_{2}$ solution of $10 \mathrm{mg} / \mathrm{L}$ drastically reduced the number of MDR-P. aeruginosa and MDR-A. baumannii bacteria within $60 \mathrm{~s}$ under conditions of a mixture containing a high concentration of bovine serum albumin and sheep erythrocytes [8]. Furthermore, the effect of inactivation by a $\mathrm{ClO}_{2}$ solution of $10 \mathrm{mg} / \mathrm{L}$ against drug-sensitive $P$. aeruginosa (1.4 $\log _{10}$ reductions, within $15 \mathrm{~s}$ ) was lower than that against MDR-P. aeruginosa (3.6 $\log _{10}$ reductions, within $15 \mathrm{~s}$ ). In other words, MDR-P. aeruginosa are more sensitive to $\mathrm{ClO}_{2}$ than drug-sensitive $P$. aeruginosa. These data suggest that extremely low-concentration gaseous $\mathrm{ClO}_{2}$ may have a bactericidal effect against MDR-GNB.

In a previous study, we discussed the fact that moisture plays an important role in the inactivation of feline calicivirus on glass dishes by $<0.1 \mathrm{ppmv} \mathrm{ClO}_{2}$ gas [9]. Hence, in this study we evaluated bactericidal activity against GNB of extremely low-concentration gaseous $\mathrm{ClO}_{2}$ in wet conditions, but not in the dry state. Previous studies are not sufficient to clarify the route of infection for
GNB in wet environments such as sinks and bathroom. However, several studies suggest that a watery environment as occurs in kitchens, drains, bathrooms, sinks and faucets serves as a reservoir for microorganisms $[10,11]$. Barker et al. showed that flushing a toilet produces aerosols containing microbes that are capable of causing surface contamination within the toilet [12]. In this study, gaseous $\mathrm{ClO}_{2}$ at an extremely low- concentration inactivated GNB in wet conditions on glass dishes as a model of microbes on surfaces in a wet environment. In addition, the extremely low-concentration gaseous $\mathrm{ClO}_{2}$ inactivated $P$. aeruginosa with $5 \%$ FBS $\left(2.9 \log _{10}\right.$ reductions $)$ within $3 \mathrm{~h}$. The percent FBS contained in a microbial suspension (minimum 5\% FBS) was designed by the United States Environmental Protection Agency (US EPA) for virucidal effectiveness testing using feline calicivirus [13]. It should be noted that the effect of inactivation of $P$. aeruginosa by extremely low-concentration gaseous $\mathrm{ClO}_{2}$ was considerably decreased in the presence of $10 \%$ FBS. Therefore, its inactivating effect may be limited under dirty conditions $(>5 \% \mathrm{FBS})$. In addition, we examined the effect of an erythrocytes load (final 0.3\% (w/v) BSA and $0.3 \%(\mathrm{v} / \mathrm{v})$ erythrocytes) on the inactivation of $P$. aeruginosa by extremely low-concentration gaseous $\mathrm{ClO}_{2}$. The extremely low-concentration gaseous $\mathrm{ClO}_{2}(0.01$ ppmv) inactivated $P$. aeruginosa with erythrocytes $(1.0$ $\log _{10}$ reductions) within $3 \mathrm{~h}$. Taken together, treatment of moist environments with extremely low- concentration gaseous $\mathrm{ClO}_{2}$ may help to reduce the risk of environmental infection by GNB without harmful effects.

\section{Limitations}

We were not able to determine the bactericidal activity of gaseous $\mathrm{ClO}_{2}$ of extremely low-concentration against multidrug-resistant (MDR)-GNB. We were also not able to evaluate the effect of organic substance load on the inactivation of $E$. coli and A. baumannii by extremely low-concentration gaseous $\mathrm{ClO}_{2}$. We were also not able to evaluate bactericidal activity of gaseous $\mathrm{ClO}_{2}$ at extremely low-concentrations against GNB in environments.

\section{Abbreviations \\ GNB: Gram-negative bacteria; $\mathrm{ClO}_{2}$ : Chlorine dioxide; SCD: Soybean Casein Digest; HAls: Healthcare-associated infections; OSHA: Occupational Safety and Health Administration; NITE: National Institute of Technology and Evaluation; D-PBS: Dulbecco's phosphate buffer saline; CFU: Colony forming units; MDR: Multidrug-resistant; OD: Optical Density; BSA: Bovine serum albumin.}

\section{Acknowledgements}

Not applicable.

\section{Authors' contributions}

$\mathrm{HM}, \mathrm{TM}$ and TS contributed to the conception and study design. HM and MF performed experiments and statistical analyses. HM wrote the draft manuscript and prepared figures. All authors read the draft manuscript and 
provided feedback about the draft manuscript. All authors read and approved the final manuscript.

\section{Funding}

This work was supported by Taiko Pharmaceutical Co., Ltd.

\section{Availability of data and materials}

All data generated or analyzed during this study are included in this published article.

\section{Ethics approval and consent to participate}

Not applicable.

\section{Consent for publication}

Not applicable.

\section{Competing interests}

The authors declare that they have no competing interests.

\section{Author details}

${ }^{1}$ Taiko Pharmaceutical Co., Ltd., Uchihonmachi 3-34-14, Suita, Osaka 564-0032, Japan. ${ }^{2}$ Kyoto Plant/R\&D Center, 1-2-1 Hikaridai, Seikacho, Soraku-gun, Kyoto 619-0237, Japan

Received: 25 December 2019 Accepted: 28 January 2020

Published online: 12 February 2020

\section{References}

1. Tacconelli E, Cataldo MA, Dancer SJ, De Angelis G, Falcone M, Frank U, Kahlmeter G, Pan A, Petrosillo N, Rodríguez-Baño J, Singh N, Venditti M, Yokoe DS, Cookson B. ESCMID guidelines for the management of the infection control measures to reduce transmission of multidrug-resistant Gram-negative bacteria in hospitalized patients. Clin Microbiol Infect. 2014;20:1-55.

2. Rodrigo-Troyano A, Sibila O. The respiratory threat posed by multidrug resistant Gram-negative bacteria. Respirology. 2017;22:1288-99.

3. Morino H, Fukuda T, Miura T, Shibata T. Effect of low-concentration chlorine dioxide gas against bacteria and viruses on a glass surface in wet environments. Lett Appl Microbiol. 2011;53:628-34.
4. Ogata N, Sakasegawa M, Miura T, Shibata T, Takigawa Y, Taura K, Taguchi K, Matsubara K, Nakahara K, Kato D, Sogawa K, Oka H. Inactivation of airborne bacteria and viruses using extremely low concentrations of chlorine dioxide gas. Pharmacology. 2016;97:301-6.

5. Occupational Safety and Health Administration (OSHA), United States Department of Labor. OSHA Annotated Table Z-1, https://www.osha.gov/ dsg/annotated-pels/tablez-1.html.

6. Akamatsu A, Lee C, Morino H, Miura T, Ogata N, Shibata T. Six-month low level chlorine dioxide gas inhalation toxicity study with two-week recovery period in rats. J Occup Med Toxicol. 2012;7:1-8.

7. Ogata N, Koizumi T, Ozawa F. Ten-week whole-body inhalation toxicity study of chlorine dioxide gas in rats. J Drug Metab Toxicol. 2013;4:1-5.

8. Hinenoya A, Awasthi SP, Yasuda N, Shima A, Morino H, Koizumi T, Fukuda T, Miura T, Shibata T, Yamasaki S. Chlorine dioxide is a better disinfectant than sodium hypochlorite against multi-drug resistant Staphylococcus aureus, Pseudomonas aeruginosa, and Acinetobacter baumannii. Jpn J Infect Dis. 2015;68:276-9.

9. Morino H, Fukuda T, Miura T, Lee C, Shibata T, Sanekata T. Inactivation of feline calicivirus, a norovirus surrogate, by chlorine dioxide gas. Biocontrol Sci. 2009:14:147-53.

10. Kizny Gordon AE, Mathers AJ, Cheong EYL, Gottlieb T, Kotay S, Walker AS, Peto TEA, Crook DW, Stoesser N. The hospital water environment as a reservoir for carbapenem-resistant organisms causing hospitalacquired infections-a systematic review of the literature. Clin Infect Dis. 2017:64:1435-44

11. Kagan $L$, Aiello $A E$, Larson E. The role of the home environment in the transmission of infectious diseases. J Community Health. 2002;27:247-67.

12. Barker J, Jones MV. The potential spread of infection caused by aerosol contamination of surfaces after flushing a domestic toilet. J Appl Microbiol. 2005;99:339-47.

13. United states Environmental Protection Agency (US EPA), virucidal effectiveness testing using feline calicivirus as surrogate for Norovirus, https:// www.epa.gov/pesticide-registration/virucidal-effectiveness-testing-using -FELINE-calicivirus-surrogate-norovirus.

\section{Publisher's Note}

Springer Nature remains neutral with regard to jurisdictional claims in published maps and institutional affiliations.
Ready to submit your research? Choose BMC and benefit from:

- fast, convenient online submission

- thorough peer review by experienced researchers in your field

- rapid publication on acceptance

- support for research data, including large and complex data types

- gold Open Access which fosters wider collaboration and increased citations

- maximum visibility for your research: over $100 \mathrm{M}$ website views per year

At BMC, research is always in progress.

Learn more biomedcentral.com/submissions 